\title{
Bioacoustic investigations and taxonomic considerations on the Cicadetta montana species complex (Homoptera: Cicadoidea: Tibicinidae)
}

\author{
MATIJA GOGALA $^{1}$ and TOMI TRILAR ${ }^{2}$ \\ ${ }^{1}$ Slovenian Academy of Sciences and Arts, Novi trg 3, SI-1000 Ljubljana, Slovenia \\ ${ }^{2}$ Slovenian Museum of Natural History, Presernova 20, SI-1000 Ljubljana, Slovenia \\ Manuscript received on January 15, 2004; accepted for publication on February 5, 2004.
}

\begin{abstract}
Recent bioacoustic investigations have shown that Cicadetta montana Scopoli 1772 is a complex of morphologically similar sister species that are best characterized by their song patterns. At the type locality of $C$. montana, only mountain cicadas with simple, long lasting song phrases were heard, recorded and collected. Therefore, we have good reasons to suggest that this type of song is characteristic for C. montana s. str. Boulard described a song of $C$. montana from France with phrases composed of a long and a short echeme; this type of song is characteristic for cicadas morphologically corresponding to C. montana var. brevipennis Fieber 1876; we suggest to raise this taxon to species level. On the basis of specific song, Puissant and Boulard described $C$. cerdaniensis from Pyrénées. A similar case was the discovery and description of $C$. montana macedonica Schedl 1999 from Macedonia; since these Macedonian cicadas are sympatric with at least two other cryptic species in the $C$. montana group and molecular investigations showed substantial genetic differences between $C$. macedonica and $C$. montana or $C$. brevipennis, we conclude that this taxon should also be raised to species level. Songs of closely related $C$. podolica and Korean mountain cicada are presented as well.
\end{abstract}

Key words: Cicadetta montana, Cicadetta spp., cicadas, bioacoustics, systematics.

\section{INTRODUCTION}

In many acoustically active animals, especially insects, the species-specific song can be used to discriminate between morphologically similar but acoustically clearly distinct taxa (e.g. Alexander and Moore 1962, Bailey 1991, Gerhardt and Huber 2002). More specifically, this has been acknowledged in cicadas for a long time. We present here vocalizations of the European species of the Cicadetta montana and $C$. podolica species groups, to document the value of using acoustic signals as speciesspecific characters. The results of our bioacoustic

Correspondence to: Matija Gogala

E-mail: matija.gogala@uni-lj.si investigations support the distinction of several taxonomically distinct, yet very similar species. A preliminary discussion about geographic distribution of newly recognized species is presented here.

\section{MATERIALS AND METHODS}

Recordings of songs of cicadas were made in the field using TELINGA PRO III and PRO V parabolic microphones (parabola diameter $57 \mathrm{~cm}$ ) connected to SONY DAT recorders TCD-D3 and TCD-D10 (sampling rate $48 \mathrm{kHz}, 16-$ bit dynamic range). Because of their high frequency range, many recordings of mountain cicadas were also done with ultrasonic (bat) detectors (Ultra Sound Advice S-25 or 
Pettersson D-200) with a microphone mounted into a Telinga parabola (see Popov et al. 1997).

In the laboratory, DAT recordings were transferred to a POWER MACINTOSH G3/233, G4 or iMAC computer through an AUDIOMEDIA III sound card or iMic adapter. Software used for viewing, editing and analyzing the song signals were DIGIDESIGN PROTOOLS 5, and CANARY 1.2. Sound spectrograms were produced with the Canary software using the following settings: filter bandwith $349.70 \mathrm{~Hz}$, frame length 512 points, FFT size 4096 points, Hamming window, logarithmic amplitude scale, smooth display style.

Voucher specimens of cicadas recorded and collected by the authors are preserved in the collection of the Slovenian Museum of Natural History (PMSL) in Ljubljana. Specimens bioacoustically investigated by French colleagues are deposited in the collections in Paris.

\section{RESULTS}

\section{Cicadetta montana SPECIES GROUP}

Only some taxa of the $C$. montana species complex have had their song patterns described. Boulard (1995) described the calling song of C. montana from France as a repeated pattern of one long echeme followed by a short one (see Fig. 1). This "binary" song pattern was also found in many populations of mountain cicadas in Slovenia (Gogala and Trilar 1999). Nevertheless, we recorded in other populations of mountain cicadas in Slovenia another song pattern. This pattern was characterized by a long buzzing sound of similar frequency range, slowly increasing in intensity but without a short echeme at the end (Fig. 2, Gogala and Trilar 1999, Gogala 2002). In Idria, around the type locality, only this second song pattern has been heard and recorded. Therefore, we conclude that this pattern is characteristic of the true C. montana described by Scopoli (1772). Our conclusion is based on many recordings of mountain cicada songs from this region. All of them were of long and simple type and none of binary or any other type. It is interesting that this song pattern was recorded from cicadas in New For- est, England (Jim Grant, unpubl. data). Further, we have recorded this type of song in some higher elevation localities in Slovenia and Macedonia. A short comparison of both taxa is shown in Table I. The Western European mountain cicada with a binary song is morphologically similar to the specimens described by Fieber (1876) as C. m. var. brevipennis. Therefore, we propose that this taxon be considered a valid species, under the name $C$. brevipennis Fieber stat. nov. A comprehensive comparison of morphology, behavior and song parameters of both taxa will be published elsewhere.

Another taxon of mountain cicadas whose song pattern is well described (Gogala and Trilar 1999), is the Macedonian mountain cicada C. montana macedonica. Due to small differences in morphology, Schedl (1999) described it as a subspecies. Our recent investigations in Macedonia have shown that these cicadas are sympatric with at least two other cryptic species in the C. montana species complex (C. cerdaniensis and C. podolica). Therefore, and due to a unique song pattern and molecular data (see below), we conclude that the Macedonian cicada should be raised to species level as C. macedonica Schedl, stat. nov.

The next species of mountain cicadas with a well-described song is $C$. cerdaniensis Puissant and Boulard 2000. This species has been described from the Pyrénées (France), where C. brevipennis is also present (Puissant and Boulard 2000). Our recent investigations in Poland (Polana Polichno) and Macedonia have shown the presence of mountain cicadas with a song pattern almost identical to that of $C$. cerdaniensis (Fig. 3). Some years ago we found near Trenta, Slovenia, a population of mountain cicadas with very similar song characteristics (Fig. 3d). Sueur and Pillet (unpubl. data) found a similar song pattern in another population of "mountain cicadas" from Switzerland. These data could indicate that $C$. cerdaniensis is another species of "mountain cicadas" widely distributed in Europe.

Within the C. montana group, bioacoustic investigations can thus be used to recognize the following taxa as valid species: $C$. brevipennis Fieber and C. macedonica Schedl, and to clearly differenti- 


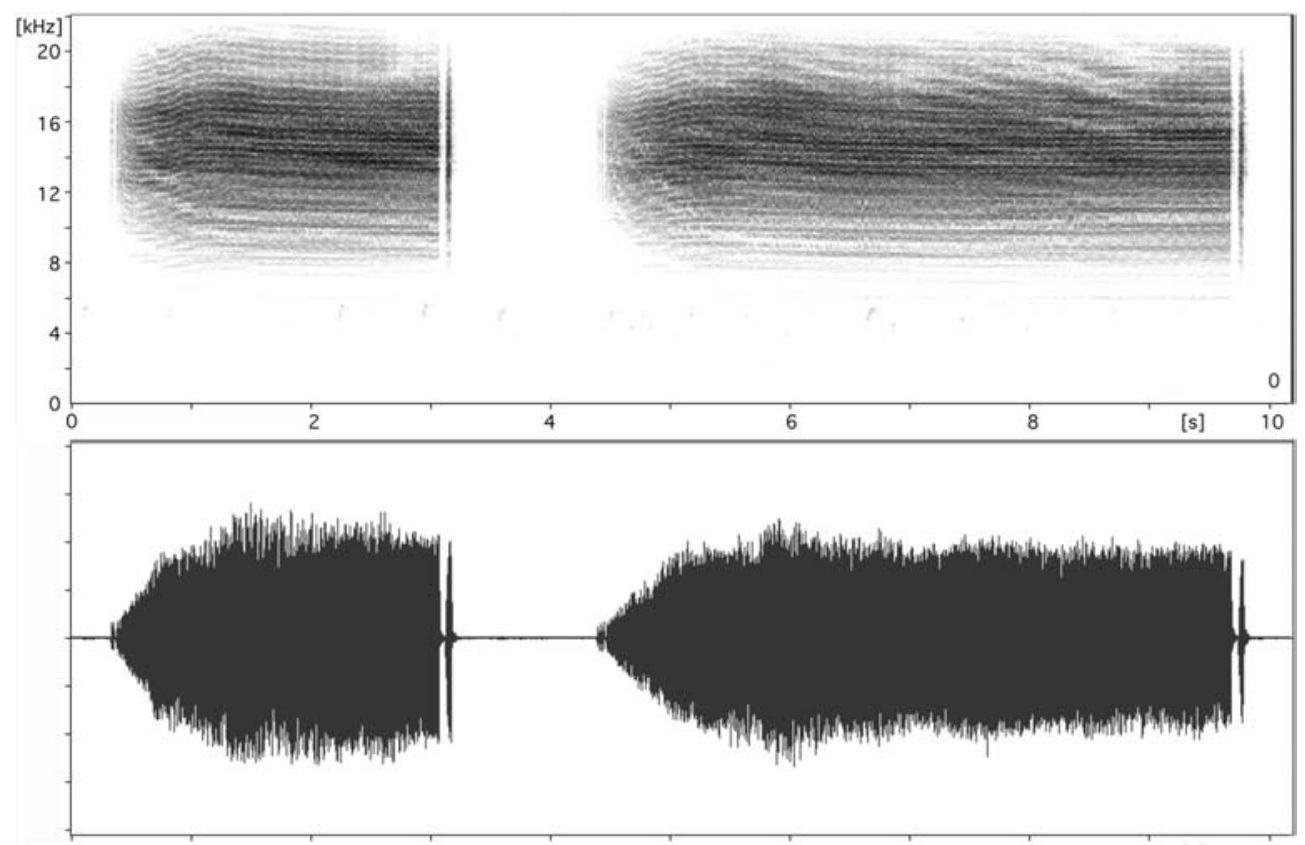

Fig. 1 - Sonogram (above) and oscillogram (below) of the calling song of the "mountain cicada' $C$. brevipennis stat. nov. from Lukovica (Slovenia). Phrases normally end with a distinct short echeme.

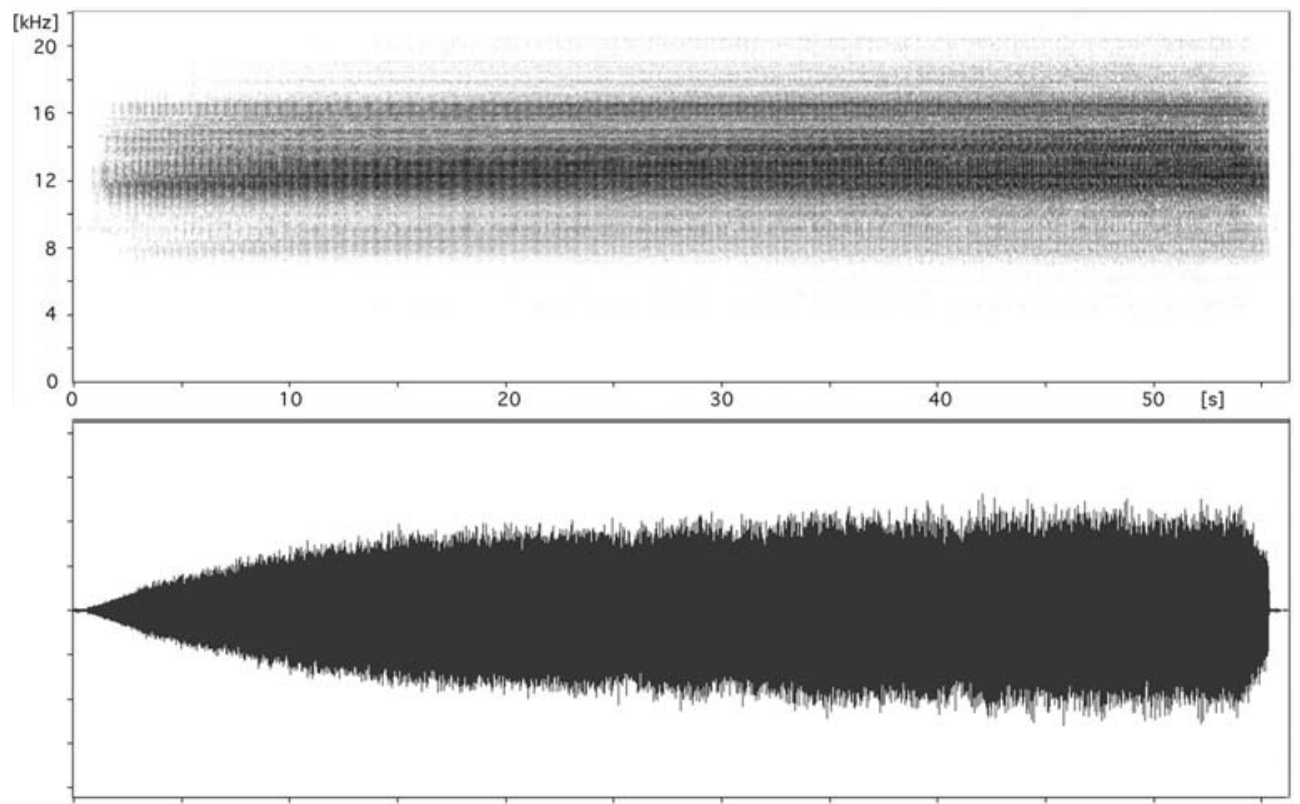

Fig. 2 - Sonogram (above) and oscillogram (below) of the song of the "mountain cicada" C. montana s. str. from Mt. Strazar near Ig, Slovenia. The time axis covers almost one minute in contrast to figure 1. 
TABLE I

Morphological and bioacoustic differences between Cicadetta montana s. str. and C. brevipennis.

\begin{tabular}{l|l|l}
\hline & C. montana s. str. & C. brevipennis \\
\hline wings & longer and slender & shorter and broader \\
\hline venation & costal vein dark & costal vein yellow \\
\hline calling song & long simple type of phrase & $\begin{array}{l}\text { short binary phrases } \\
(\text { long }+ \text { short echeme })\end{array}$ \\
\hline Phrase duration & $43.6 \pm 29.7 \mathrm{~s}$ & $4.2 \pm 3.3 \mathrm{~s}$ \\
\hline Singing places & on treetops & on trees, shrubs and in grass \\
\hline
\end{tabular}

ate them from their close relatives, $C$. montana and C. cerdaniensis.

\section{Cicadetta podolica Species Group}

Morphologically easily discernible from other cicadas of the $C$. montana group is the steppe cicada Cicadetta podolica Eichwald 1830. The morphological characteristics, ecology and geographical distribution were reviewed recently by Schedl (1986). In 2003 we visited a well-known locality of this species: Krzyzanowice, Nida valley in Poland. Due to unsuitable weather conditions we recorded only a song of one animal. The repeated phrase of this song comprises a sequence of short echemes followed by a long echeme (Fig. 4).

In Macedonia, we found an isolated population of cicadas of similar but different morphology and acoustic pattern (Fig. 4). This taxon could represent a subspecies of $C$. podolica. The similarity in the song pattern compared to the song of $C$. podolica from Poland is obvious. Nevertheless, some parameters of the song differ substantially in the Macedonian population as compared to the song phrases of the one recorded specimen from Poland (see Table II).

\section{Female Clicks and Courtship Songs}

Puissant (2001) described a distinct courtship song of $C$. brevipennis - under the name of C. montana. Similar courtship song patterns of the same species have also been recorded in Slovenia. From the recordings of the courtship of $C$. montana from England by Jim Grant, one can conclude that the males of C. montana s. str. do not have a distinct courtship song, but that females produce short clicks during courtship by wing flipping. Similar observations were made of courtship in C. cerdaniensis in Polana Polichno (Poland). Exact observations are needed to clarify this behavior in this and other species of C. montana group.

\section{DISCUSSION}

\section{Systematic Considerations}

Recent acoustic investigations of songs of mountain cicadas have shown the complexity of this group of insects. Despite the very similar appearance of these cicadas (Puissant and Boulard 2000, Schedl 1999, Gogala and Trilar 1999), in many localities acoustically easily distinguishable populations live sympatrically. Moreover, the adults appear and sing at the same place and at the same time of the year. Since the species-specific songs are important in species recognition and in the mating process (Gerhardt and Huber 2002), this means that they are reproductively isolated and can therefore be considered separate species.

The type locality of Cicadetta montana has been described by Scopoli (1772) with the following words: "In montanis Carnioliae circa Idriam". Today, only the mountain cicadas with a long lasting continuous song exist in this locality. Consequently, we can hypothesize that this type of song is characteristic for C. montana "sensu stricto". Unfortunately, this hypothesis cannot be confirmed by direct comparisons of recorded specimens with Scopoli's type, since his collection does not exist any more. 

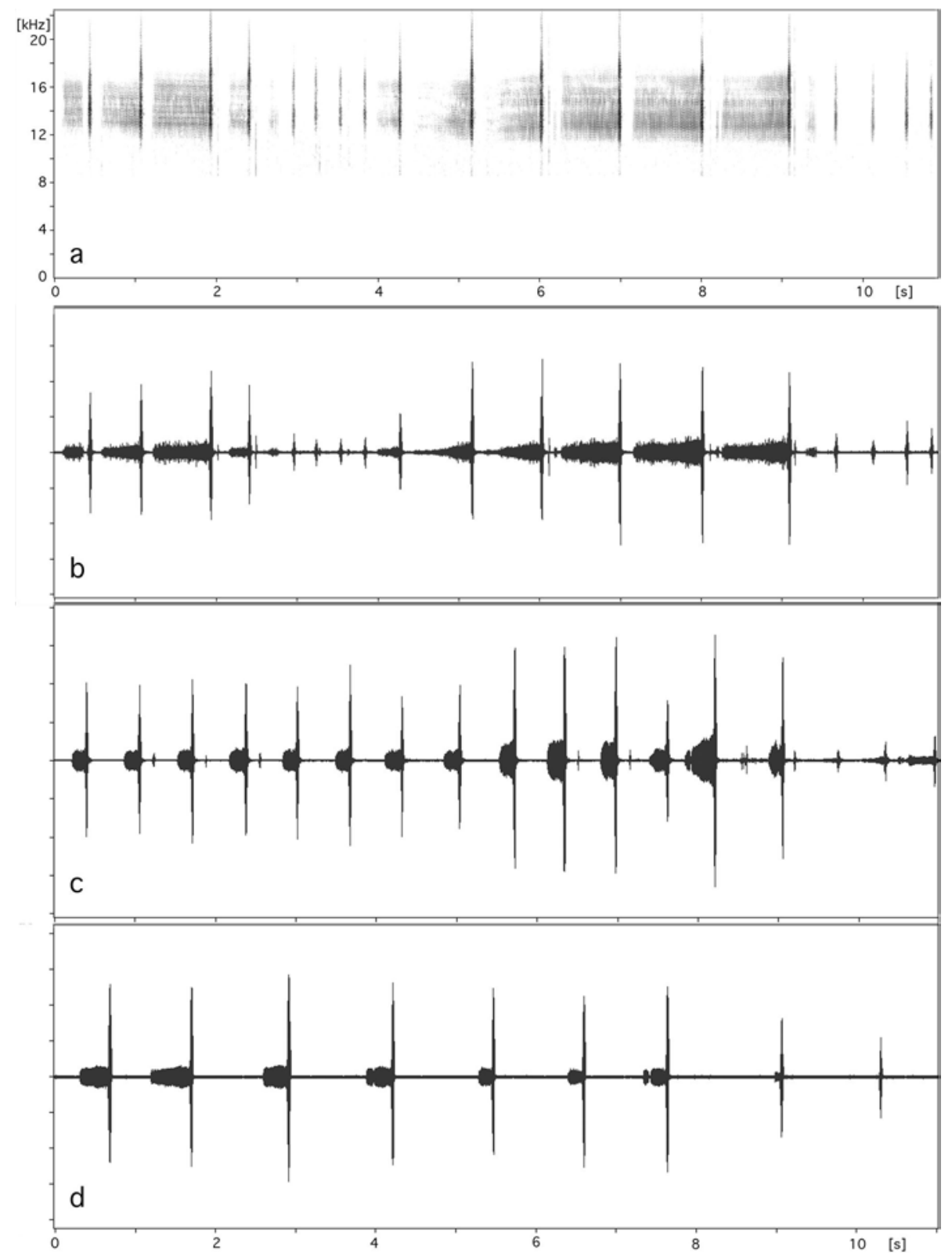

Fig. 3 - Sonogram (a) and oscillograms (b-d) of the song of C. cerdaniensis. Recordings were made in Polana Polichno, Poland (a and b), Suva Planina, Macedonia (c) and Trenta valley, Slovenia (d).

According to some morphological characteristics, especially the form of the wings and coloration of veins, we assume that this type of mountain cicadas corresponds to the C. $m$. var. longipennis described by Fieber (1876), but detailed morphological comparison is needed to support this assumption.
On bioacoustic grounds, among the C. montana species group we propose to raise as valid species C. brevipennis Fieber, 1876 stat. nov. and C. macedonica Schedl, 1999 stat. nov. New morphological studies on specimens with known types of songs are necessary however to find clear differential char- 

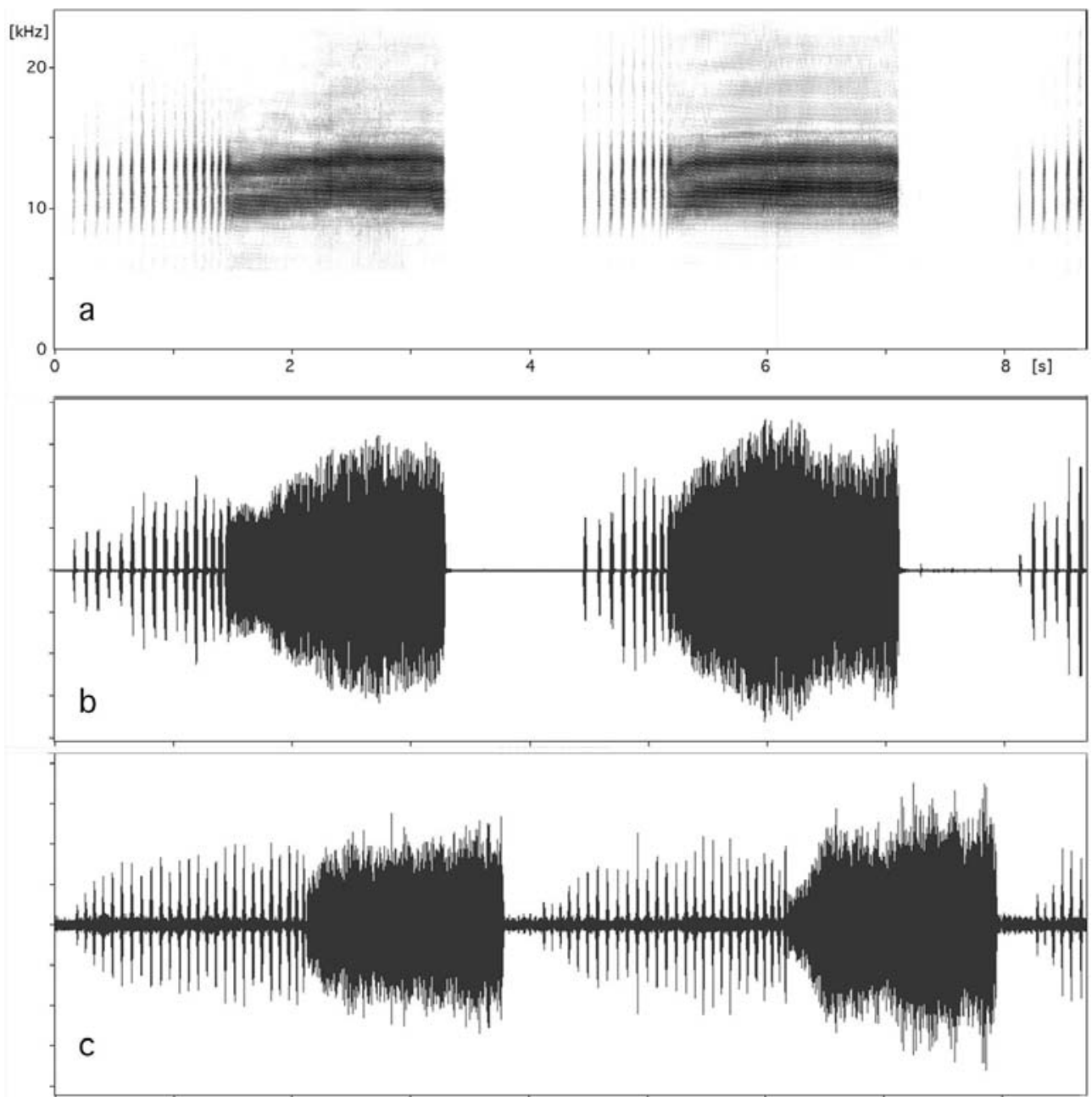

Fig. 4 - Sonogram (a) and oscillograms (b-c) of the song of C. podolica. Recordings were made in Suva Planina, Macedonia (a and b) and Krzyzanowice, Poland (c).

TABLE II

Differences in song parameters between two populations of Cicadetta podolica. $\mathrm{SE}=$ short echeme $; \mathrm{LE}=$ long echeme.

\begin{tabular}{l|l|l}
\hline & Poland & Macedonia \\
\hline SE duration & $14.37 \pm 3.41 \mathrm{~ms}$ & $22.63 \pm 5.52 \mathrm{~ms}$ \\
\hline SE interval & $60.07 \pm 11.54 \mathrm{~ms}$ & $64.14 \pm 20.48 \mathrm{~ms}$ \\
\hline LE duration & $2.15 \pm 0.46 \mathrm{~s}$ & $1.78 \pm 0.29 \mathrm{~s}$ \\
\hline Phrase interval & $0.4 \pm 0.08 \mathrm{~s}$ & $1.04 \pm 0.14 \mathrm{~s}$ \\
\hline Number of SE & $30 \pm 8$ & $13 \pm 3$ \\
\hline
\end{tabular}


acters between these two and other closely related species of this complex.

Dan Vanderpool and Chris Simon from Storrs, Connecticut did molecular analyses of our samples of mountain cicadas from specimens with previously recorded songs. From these investigations the Bayesian phylogram, estimated from 1500 bp COI and COII mitochondrial DNA, was constructed with branches indicating posterior probability of bipartition. This phylogram supports our distinction between C. montana s. str., C. brevipennis stat. nov. and $C$. macedonica stat. nov. The estimated time of bifurcation of the latter is about 2 million years ago (Vanderpool and Simon, pers. comm.).

Similar taxonomic conclusions could be drawn for C. podolica Eichwald, 1830 and a yetundescribed population from Macedonia. In addition to the differences in song parameters (Table II), we found differences from typical $C$. podolica in the song ultrastructure: in the recording from Poland tymbal clicks present twice the repetition frequency of the Macedonian ones, probably due to asynchronous action of both tymbals.

Finally, in addition to the species of C. montana complex described above, we can mention preliminary data on other cicadas from this group. Many years ago Popov recorded in Georgia mountain cicadas with a pattern unlike any other described song. Beside the long continuous buzzing sounds similar to the songs of $C$. montana s. str., he recorded relatively short echemes of approximately half second duration and a repetition rate of about 23 echemes per minute (Popov, pers. comm.). Lee (1998) reported the presence of $C$. montana in Korea. Later he also recorded the song with a simple recording device (unpubl. data). After some filtering and amplification we were able to clean this recording and to make a comparison with other song patterns. It partly resembles $C$. brevipennis (by binary structure) and partly C. cerdaniensis (by much higher amplitude of the second echeme in a phrase) song patterns, but it is still clearly different from all other known song patterns of mountain cicadas (Fig. 5).

The situation described here could be of a wide significance in cicada research and demonstrates the further necessary use of biological, in this case bioacoustical, characters in systematics.

\section{Geographic Distribution}

Due to the fact that the $C$. montana group is a complex of sister species, we have to reinvestigate their geographic distribution under the light of acoustic data. During our recent examinations we found out that C. montana s. str. is present in Great Britain, Germany, Slovenia, Macedonia and probably also in France, Switzerland, Austria, Italy, Croatia, and in other countries of the Balkan Peninsula including Greece. C. brevipennis is present in Western and Central Europe with the exception of Great Britain. The actual data are from France, Germany, Italy, Slovenia, and the probable range covers also Switzerland, Austria, Croatia and some other Central European countries. C. cerdaniensis is present in France, Switzerland, Poland, Slovenia, Macedonia and very probably also in the neighboring countries (Italy, Germany, Austria, Croatia and other countries of the Balkans).

Eastern Europe and central Asia are also inhabited by cicadas of the C. montana group, but we do not have enough data about them to make any conclusion. Even in the Far East (e.g. Korea) there are related taxa of this complex of sister species, but further bioacoustic, molecular and morphological investigations are needed to clarify their taxonomic and phylogenetic relationships.

A species closely related to the $C$. montana complex is $C$. podolica with its yet undescribed form from Macedonia. For this morphologically distinct species only minor changes in the knowledge of their distribution range can be expected. One such new discovery is that of the Macedonian population.

\section{CONCLUSION}

Our acoustic studies as well as molecular investigations support the opinion that the C. montana group is a complex of morphologically very similar species. Most species are best characterized by a distinct and species-specific song pattern, some of which are yet undescribed. We have substantially changed our understanding of the geographic distri- 


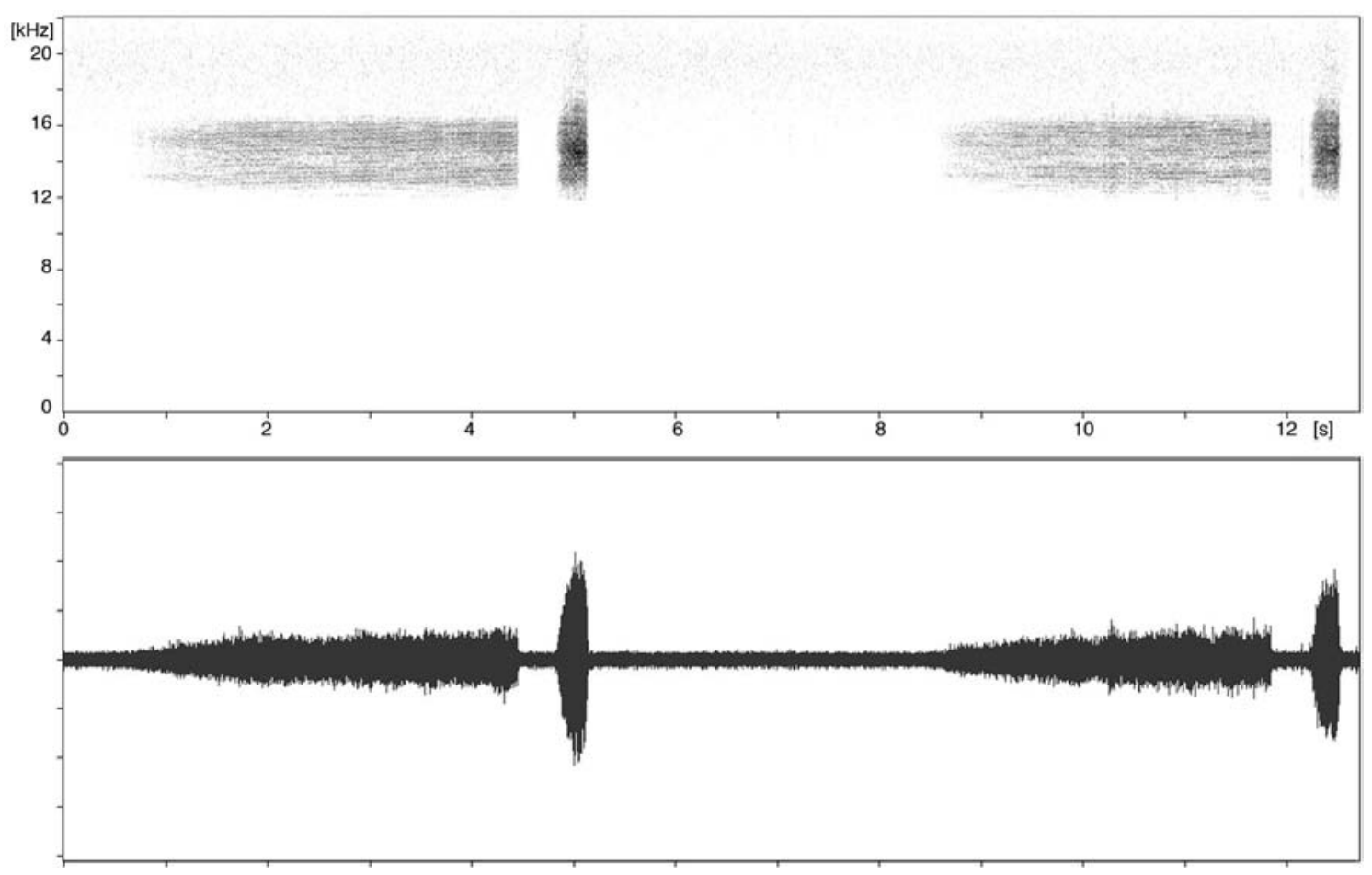

Fig. 5 - Sonogram (above) and oscillogram (below) of the song of $C$. cf. montana song from Korea (recorded by Lee and published with his permission). Binary structure of this song is similar to C. brevipennis and amplitude modulation reminds the C. cerdaniensis song.

bution of the species within this group. Therefore the data about the distribution of the Cicadetta montana complex of species should be reinvestigated in Europe and Asia with especial emphasis on the acoustic pattern of their songs.

\section{ACKNOWLEDGMENTS}

The research was supported by the Slovenian Museum of Natural History, Slovenian Academy of Sciences and Arts, and especially in the field, by the help of the colleagues Vlado Krpac MSc., Macedonian Museum of Natural History, Skopje, Macedonia, Jacek Szwedo, Polish Academy of Science, Warszaw, Poland, Andrej Kapla, Hrastnik, Slovenia. We are grateful to Andrej Gogala for preparation of specimens, taking care of Hemiptera collection and for many valuable data and observations in the field. Nina Mijatovic and Masa Hrescak evaluated parameters of our tape recordings in the frame of their graduation theses. We are also grateful for some data and recordings of Stephane Puissant, Jérôme Sueur - France, Andrej V. Popov, St. Petersburg Russia and of Young J. Lee - Korea. Chris Simon and Dan Vanderpool from the University of Connecticut, Storrs, USA, provided valuable molecular genetic data of our samples and kindly allowed us to use these data in our paper. We would also like to express our thanks to Ms Lena Ward, who gave us permission to use and evaluate the recordings of English mountain cicadas recorded by her late husband Jim Grant.

\section{RESUMO}

Pesquisas recentes de bioacústica mostraram que Cicadetta montana Scopoli 1772 é um complexo de espécieirmãs morfologicamente semelhantes e melhor caracterizadas por seus padrões de canto. Na localidade-tipo de C. montana somente cigarras serranas de longas frases de canto foram ouvidas, gravadas e coletadas. Portanto, 
temos boas razões para propor este tipo de canto como característico de $C$. montana s. str. Boulard descreveu um canto de $C$. montana da França com frases compostas de uma estridulação longa e uma curta; este tipo de canto é característico das cigarras correspondendo morfologicamente a C. montana var. brevipennis Fieber 1876; sugerimos elevar este táxon ao nível de espécie. Baseandose nos cantos específicos, Puissant e Boulard descreveram C. cerdaniensis dos Pirineus. Um caso similar foi a descoberta e descrição de C. montana macedonica Schedl 1999 da Macedônia; desde que essas cigarras macedônicas são simpátricas com pelo menos duas outras espécies crípticas dentro do grupo C. montana e as análises moleculares mostraram diferenças genéticas substanciais entre C. montana e C. brevipennis, concluímos que este táxon também deve ser elevado ao nível de espécie. Cantos de espécies próximas, $C$. podolica e a cigarra serrana da Korea, são também apresentados.

Palavras-chave: Cicadetta montana, Cicadetta spp., cigarras, bioacústica, sistemática.

\section{REFERENCES}

Alexander RD and Moore TE. 1962. The evolutionary relationships of 17-year and 13-year cicadas, and three new species (Homoptera, Cicadidae, Magicicada). Misc Publ Mus Zool Univ Mich 121: 1-59.

Bailey WJ. 1991. Acoustic Behaviour of Insects. London: Chapman and Hall, 225 p.

Boulard M. 1995. Postures de cymbalisation, cymbalisations et cartes d'identité acoustique des cigales. 1Généralités et espèces méditerranéenes (Homoptera, Cicadoidea). EPHE Biol Evol Insectes 7/8: 1-72.

Fieber FX. 1876. Les Cicadines d'Europe d'après les originaux et les publications les plus récentes. Deuxième partie. Revue et Magasin de Zoologie (3) 4: 11-268.

Gerhardt HC and Huber F. 2002. Acoustic communication in insects and anurans. Chicago: University of Chicago Press, 531p.
Gogala M. 2002. Gesänge der Singzikaden aus Südost- und Mittel-Europa. In: Holzinger WE. (Ed), Zikaden: Leafhoppers, Planthoppers and Cicadas (Insecta: Hemiptera: Auchenorrhyncha). Linz: Kataloge des OÖ. Landesmuseums, N.F., Denisia 4: 241-248.

Gogala M and Trilar T. 1999. The song structure of Cicadetta montana macedonica Schedl with remarks on songs of related singing cicadas (Hemiptera: Auchenorrhyncha: Cicadomorpha: Tibicinidae). Reichenbachia Schriftenreihe Taxonom Entomol 33: 91-97.

LEE YJ. 1998. Habitat and habits of Cicadetta montana (Homoptera, Cicadidae) in Korea. Cicada 13: 19-21.

Popov AV, Beganovic A and Gogala M. 1997. Bioacoustics of singing cicadas of the western palaearctic: Tettigetta brullei (Fieber 1876) (Cicadoidea: Tibicinidae). Acta entomologica slovenica 5: 89-101.

Puissant S. 2001. Eco-éthologie de Cicadetta montana (Scopoli 1772) en France (Auchenorrhyncha, Cicadidae, Cicadettini). EPHE Biol Evol Insectes 14: 141-155.

Puissant S and Boulard M. 2000. Cicadetta cerdaniensis, espèce jumelle de Cicadetta montana décryptée par l'acoustique (Auchenorrhyncha, Cicadidae, Tibicinidae). EPHE Biol Evol Insectes 13: 111-117.

SCHEDL W. 1986. Zur Morphologie, Ökologie und Verbreitung der Singzikade Cicadetta podolica (Eichw.) (Homoptera: Auchenorrhyncha, Tibicinidae). Ann Naturhist Mus Wien 88/89: 579-585.

SchedL W. 1999. Eine neue Unterart der Bergsingzikade im Balkan, Cicadetta montana macedonica ssp.n. (Hemiptera: Auchenorrhyncha: Cicadomorpha: Tibicinidae). Reichenbachia Mus Tierkd Dresden 33: 87-90.

Scopoli JA. 1772. Annus V. Historico Naturalis V. Observationes zoologicae. Lipsiae, p. 109-110. 